\title{
Justice and Legal Certainty For Child Victims
}

\author{
EDI SETIADI \\ Fakultas Hukum Universitas Islam Bandung \\ email: edistd@yahoo.com
}

\begin{abstract}
Focus of attention in the criminal justice system so far has always been to the perpetrator, whereas parties related to a process of criminal justice encompasses the perpetrator, the victim, and the community. A crime victim, in particular, would suffer more since he/she could experience secondary victimization in the criminal justice system. The law concerning victim and witness protection only states the limitation for the criminal victim to ask for compensation to criminal justice system, either as a victim of direct criminal or a victim of abuse power done by law enforcement officers. Child victims are treated the same way as to adult victims, whilst they have a greater dimension of the problem and effects to be dealt with. Mechanism and procedures to be followed are ius constituendum (intended/desirable law), as they only share expectation of indemnity, compensation, and rehabilitation which have not been empirically tested in a real situation.
\end{abstract}

Keywords: child victims, the criminal justice system, legal protection

\section{Introduction}

Children who are living in the presentday need to get attention from all elements of society, primarily from the government due to its constitutional obligation to give welfare to its subjects, in casu (particularly), children. Many children live on the street and receive food from people who felt pity for them. They have no access to the joy and fun of their childhood.

According to data published by UNICEF, more than three million children trapped in dangerous life and more than 100 thousand of children and women were trafficked every year with 70 thousand of children had been victims of sexual exploitation. Indonesia Commission for Child Protection (KPAI) in Indonesia recorded 140 cases of child trafficking throughout the year of 2013, children who became victims of physical and sexual abuse $(58 \%$ or 12.5 million of the cases were sexual abuse and occurred with the highest rate in Jakarta), and children who suffered mental/emotional abuse in their social environment (Forum Keadilan. 2013, 09 March. 44th Edition. Page 23). KPAI further noted that in a period of 2010-2014 there were 21.6 million cases of violence against children (the data were taken from 179 cities and regencies of 34 provinces in Indonesia).

Violence against children occurs almost every day and enhances frequently. Spiral of violence is spinning from time to time and move around in many directions. A violence only lead to another violence and that is why treatment for victims of violence would never be something easy to do. All of the communities and public elements should be united together to prevent children of becoming victims of violence or other crimes.

Various form of violence exposed to children has been taken hopelessly. By reason of physical and mental immaturity, children are powerless over violence perpetrated by adults. This is the reason we should protect the children and prevent such events to be occurred since childhood life would determine a life of a nation in the future.

Indonesia has ratified the Convention on the Right of The Child declared by The United Nations, which proclaimed that a child needs special safeguard and care, including appropriate legal protection. Accordingly, we are obligated to fulfill basic principles of child

Received: July 19, 2016, Revision: October 20, 2016, Accepted: December 30, 2016

Print ISSN: 0215-8175; Online ISSN: 2303-2499. Copyright@2016. Published by Pusat Penerbitan Universitas (P2U) LPPM Unisba Accredited by DIKTI. SK Kemendikbud, No.040/P/2014, valid 18-02-2014 until 18-02-2019 
rights, which are non-discrimination, the best interest of the child, the right to survival and development, and respecting the opinion of a child.

\section{The Existence of Victim in Positive Law}

The term of a victim is normatively unknown in Indonesian Criminal Code. It is only explained the term of compensation which could be convicted to the perpetrator/ offenders. The word of a crime victim is only stated in the terminology of law in criminology and victimology, which later be developed through or in the criminal justice system. The term of crime victim can be viewed from the broad and narrow sense of definition as many scholars have expressed in their work (for example, the opinion of Arief Gosita, Muzakir, etc.). The victim defined in the broad sense as a person or persons who have suffered harm or loss as a result of the criminal or non-criminal act. Whilst victim in the narrow sense defined as a victim of a crime.

Lilik Mulyadi (2012: 157) explained that victims in perspective of criminal law, as a result of the criminal act, can be classified into:

(1) Victim of crime, as it is stated in The Indonesian Criminal Code by which a perpetrator would get convicted. (2) Victim of abuse of power or political victimization.

(3) Victim of an administrative offense which caused an administrative sanction. (4) Victim of a norm violation in community life which caused social sanction.

The terminology of a victim in the international document can be found in the Declaration of Basic Principle of Justice for Victims of Crime and Abuse of Power (UN Convention 1985) which classified a victim into a victim of crime and victim of abuse of power.

Victim of crime means a person who, individually or collectively, have suffered harm, including physical or mental injury, emotional suffering, economic loss or substantial impairment of their fundamental right, through acts or omissions that are in violation of criminal laws operative within member states, including those laws proscribing criminal abuse power. Whilst Victims of abuse of power means person who, individually or collectively, have suffered harm, including physical or mental injury, emotional suffering, economic loss or substantial impairment of their fundamental right, through acts or omissions that do not yet constitute violations of national criminal laws but of internationally recognized norm relating to human right.

Specific opinion presented by Muladi which said that the definition of a victim of crime means a person or persons who have suffered a loss as a result of the criminal act or his/her sense of justice has been violated as an impact of his/her experience of being criminally targetted (Muladi, 2002: 177). Various terms of a victim can also be found in several articles of law and regulations which expressed in different term and meaning. Take the example of the term "plaintiff" (article 108 Criminal Code Procedures / KUHAP, article 32-34 of The Government Regulation as a Replacement of Law Number 1 Year of 2002 Jo Law Number 15 Year of 2003, article 83-87 Law Number 8 Year of 2010), the term of "complainant" (article 72 KUHAP), "witness of the victim" (article 160 KUHAP), "a third interested party" (article 80-81 KUHAP), "a third injured/harmed party" (article 98,99 KUHAP), and the term of "individual, community, and state" (article 18, 41,42, Law Number 31Year of 1999 jo Law Number 20 Year of 2001).

The meaning of victim is also implicited in various of other law and regulations, such as in article 1 section 3 Law Number 23 Year of 2004 on Domestic Violence and article 1 section 2 Law Number 13 Year of 2006 on Protection of Witnesses and Victims. The matter of victim is also regulated in the Government Regulation number 33 Year of 2003 on Compensation, Restitution, and Rehabilitation of Crime Victims of Major Human Rights Violation, the Government Regulation Number 24 Year of 2003 on procedures of protection for witnesses, investigators, prosecutors, and judges involved in terrorism cases, the Government Regulation Number 57 Year of 2003 on procedures of special protection for reporting parties and witnesses on crime against money laundering, the Government Regulation Number 4 Year of 2006 on cooperating in recovery of victims of domestic violence, the Government Regulation Number 9 Year of 2008 on the procedure and mechanism of integrated services for witnesses and/ or victims of human trafficking, and the Government Regulation Number 44 Year of 2008 on granting compensation, restitution, and assistance for the witnesses and the victims.

The law experts and scholars have 
emphasized the urgent of granting legal protection for victims of crime. Barda Nawawi Arif stated that protection for the crime victims can be viewed from two meanings: (1) It can be seen as the legal protection for preventing the case of becoming crime victims, (2) Compensation for the victims can be seen as the protection to obtain legal indemnification upon persons suffered of loss or had become victims of a criminal act (Barda Nawawi Arif, 2007: 61). That statement can be compared to the opinion of Mardjono Reksodipuro which explained that based on criminological approach, there are several reason to why the crime victims need to be paid attention to (1) the criminal justice system is considered to give more attention to the case and the perpetrator (offender-centered), (2) There is a potential of information from the crime victims to make a case clear and to complete the interpretation of crime statistics, (3) it is urgent to realize that victims of non-conventional crime or abuse of power have the equal importance of those who suffered from criminal act (Mardjono Reksodipuro,1994:102).

By logical and common sense, every victim of crime should be given a legal protection. There are two reasons as a background for the statement. Firstly, the victim of crime needs treatment for his/her serious wound (physically and mentally) and to eliminate the desire to do a revenge to the perpetrator which kept unchannelled inside their mind. The state takes over the right of the victim to press charges to the perpetrator/ offender in order to minimize the potential individual harm of revenge and to effectuates the appropriate filing of charges based on rational consideration. By applying those actions, the victims would feel represented. Secondly, it has been a constitutional obligation for the state to protect the victim of crime as consequences of embodiment ideals of the state to sustain the life and welfare of its citizen. The protection of victims is considered as an important factor since it would heal the disconnection of solidarity and social binding caused by a criminal act. In the case of crimes against children, it is important to always base every measure taken to the philosophy of "resolution for the conflict" as the primary purpose.

Sometimes great ideas fail to meet reality. It is also applied to the case of a criminal act where victim as a party suffered from harm and loss fails to receive appropriate attention and keeps separately from the criminal justice system. Stephen Schafer said in his book titled "The Victims and His Criminal" that such statement is similar to cinderella in criminal law book (Stephen Schafer, 1968: 8). Likewise, Robert Reif noted that the problem of crime is always narrowed to "what can be done about criminals" and nobody asks "what can be done about victim" (Lilik Mulyadi, 2007: 127-132). Criminal law in Indonesia still applies such system since it is oriented to the perpetrator, whilst the victim party represented only by the prosecutors who perform their duties on behalf of the interests of the crime victim which in certain cases showed the slow process of prosecution and therefore, lessen the importance of the victim interest. The crime victims who suffered loss and harm were formerly the dominant actors. The state, as a formal representation of the community, took over the right of the victim to control their cases. As a result, the crime victims slowly considered as the forgotten people and no longer become the target of the criminal justice system. Another thing which should also be a consideration in this matter is a collective protection for the victims of environmental crime which is often neglected by concerned parties.

\section{Basic of Protection for The Victims}

Several provisions imply protection for victim of crime, such as The Criminal Law Code (KUHP) article $14 \mathrm{c}$ section (1) stated that by the order referred to in article 14a, the judge may, except in case of sentence of penalty and in addition to the general condition, that the sentenced person shall not commit a punishable act, fix a special condition that the sentenced person shall, within a fixed period of time shorter than the probation period, compensate wholly or partly for damages caused by the punishable act.

The provision which implies protection for a victim can be seen from the statement of penalty sentence to the perpetrator and granting of compensation for the victim. Nevertheless, it is facultative to nature since the victim requires imperative implication that obligates the judges to include compensation in the verdict. Subsequently, a suggestion submits to the renewal criminal law code put such provision as substantial criminal law.

The protection for victim has already been initiated in the Code of Criminal Law Procedure (KUHAP). The victim of crime has a right to control the case which put him/her in his/her recent position, if the legal process 
concerning his/her case has been terminated, through legal attempts such as pretrial phase (known as the right of control). There is also joinder of cases of claims for compensation regulated in article 98 to 1010f KUHAP for material compensation instead of immaterial.

Article 99 section (1) KUHAP stated "if the injured party seeks joinder of his claim with the criminal case as intended by article 98 , the district court concerned shall consider its competence to adjudicate said claim, the veracity of the basis of the claim, and the order requiring reimbursement of costs expended by said injured party.

The phrase of "reimbursement of costs expended by said injured party" can be construed as a material loss and indemnified by material compensation, whereas immaterial compensation cannot be indemnified directly since it requires complete evidence and should undergo regular case of a trial. If it filed coincided with joinder of cases, the claim said above is unacceptable (niet onvankelijke) (M. YahyaHarahap, 2005: 82)

According to the explanation, it can be concluded that mutatis mutandis of KUHAP or any other positive laws has not given an appropriate and proportional attention to the crime victim (JE Sahetapy, 1987: 39) and the existed protection for the victim at the present is indirect (Barda Nawawi Arief, 1998: 58). Therefore, in the renewal of KUHAP which would be held in the future, a larger proportion of role should be given to the victims who submit legal attempts and experience unsatisfaction with the verdict of a criminal case or claims of compensation. Addition to that, the regular law procedure of claims of compensation should not be separated by the competence of criminal justice or civil justice.

Other legislations to KUHP and KUHAP which concerned the matter of victims can be viewed in Law Number 7 Year of 1955 on Economic Crime, Law Number 8 Year of 1999 on Consumer Protection, Law Number 5 Year of 1999 on Prohibition of Monopolistic Practices, Law Number 26 Year of 2000 on Human Rights Tribunal, Law Number 31 Year of 1999 jo Law Number 20 Year of 2001on Eradication of Corruption, Law Number 23 Year of 2004 on Domestic Violence, Law Number 13 Year of on Protection of Witnesses and Victims, Law Number 21 Year of 2007 on The Eradication of The Criminal Act of Trafficking in Persons, Law Number 32 Year of 2009 on Environmental Protection and
Management, etc.

The laws mentioned above, after having close studied, contain and imply several provisions as a form of legal protection, either material or immaterial, for the victims.

Thereby, based on those law provisions, the victims actually have a central position in criminal justice system by theory or practice. The theoretical study has shown the amendment of criminal law orientation which formerly concentrates on victimology of art to victimology of action which supports movement care for crime victims (Matt Joutsen, 1987: 151). The renewal of criminal law which put the crime victims in a central position is still be debated. Muzzakir explicitly said that a criminal act or violation against the criminal law is not only composed of one party which called offenders/perpetrator, but there is also a second party which called victims (Mudzakir, 2001: 295). The reality has shown that offenders shared the most attention rather than the victims. The question would be why does it occur and what would happen to the victims? According to the concept of the law to protect and guard all citizen, it has become an obligation of the law to perform its concept into reality and protect all persons whether he/she as the offender, the accused, the defendant, the convicted, or the victims. The offender of the criminal law with his status of whether as the accused, the defendant, and the convicted has received an appropriate legal protection, whilst the victim of crime in his/her status as the plaintiff, the witness, and the injured/harmed party in criminal law has not received the same treatment in legal protection.

Then, it is expected that the renewal of the criminal law would apply the equal treatment for both parties, the offender/ perpetrator, and the victims, without focusing on nor neglecting one party or the other. A policy made for the victim should not prioritize the victim only, but also apply for both the offender and the victim (Mudzakir, 2001: 295).

Displacement of attention of the criminal law and the criminal justice system from the offender to the crime victim has a rational basis. Firstly, that displacement would create a comprehensive criminal law system and criminal justice system in form of equal treatment and attention to both offender/perpetrator and the victims (daaddader strafrecht). David Austern stated that "the single most important prerequisite to 
effective law enforcement is the willingness of crime victims to cooperative", (David Austern, 1987: 9). Secondly, according to the principle that law is made to protect all the citizen, then the criminal justice system have to be able to balance and perform proportional measures which would maintain all the interest of every party related to the law. Unfortunately, a different situation occurs at the moment in which verdicts of the court are mostly oriented for the interest of the perpetrator rather than for the victims (or it can be said never think about a victim).

Thirdly, the displacement also happened in the conflict of criminal law where retributive paradigm changes into restorative justice. The conception of crime is accepted to be an act of violation against individual interest with restitution as part of the criminal law process. Theory of restorative justice put numbers of higher values for the victims to be more involved in the judicial process. The victims regarded as the elements of control against the course of justice. The perspective of restorative justice demands a cooperation among the perpetrator, victim, community, and government to reconcile the conflict that has occurred as well as settled the losses/damages and ensuring safety in the community at the same time. The description of restorative justice can be found in article 5 section (1) of The Law Number 48 Year of 2009 on Judicial Power asserted that "Judges shall digging, follow and understand the values of law and justice in society. It can also be seen in the provision of article 79 The Law Number 3 The year of 2009 which provide the flexibility for the supreme court to further regulate on matters which required for the implementation of a judicial process that has not been regulated yet in this law. The provision implies that positivism which has been adopted by the court have shifted to sociological jurisprudence concept. The detailed concept of restorative justice constitutes in the UN Convention on drug control and crime prevention which stated "restorative justice is a new term for an old concept, throughout the history of humankind restorative justice approaches have been used in order to solve the conflict between parties and to restore peace in communities. Retributive or rehabilitative approaches to crime are, by comparison, relatively new approaches.In recent years, however, dissatisfaction with the retributive and rehabilitative approaches has given rise to a renewed interest in restorative justice".

\section{(UN Convention 1985).}

When justice system refers to that UN Convention, then the interest of the perpetrator, the victims, and the community would be accommodated and implemented by the judges. Thus, by logical consequences, the criminal justice in Indonesia should refer to the concept or model of the balance of interests (daad dader strafrecht) rather than to the two models that have been already applied in the criminal justice system which known as Crime Control Model and Due Process Model. Both models are incompatible if they applied in Indonesia.

\section{Child Victims in The Criminal Justice System}

The introduction of this article has already mentioned that there are many children who became the victims of crime and they were powerless to avert it. Focus of attention of this article is to measure to what extent has the law provided the victims with legal protection.

Legal protection for the victims (adult victims in general) could also be applied to the child victims as well. The first thing to do before discussing the legal protection for child victims is to take a look at the criminal justice system toward children and other provisions on child welfare.

The criminal justice system toward children is the justice system particularly separated and intended for children to get legal protection and their human rights attached to them. This separation is conditio sine quanon because a child is a human under the age (of being responsible for their own life). They are a vulnerable group of humans which require particular justice system apart from the criminal justice system in general (Barbara Henkes, 2000: 87). The criminal justice system for children constitutes as one of the elements of the criminal justice system concerning of treating the cases of child misbehavior with the focus of attention on a mechanism of child cases settlement. The police as a sub-system of the criminal justice arethe first instrument in the system which has the responsibility to decide whether the offender (a child who have committed an offense) would be freed from allegations or subjected to a further legal process. Subsequently, the prosecutors and the parole institution would determine whether to free the child or bring him/her to court. The next phase is the court for children which would 
stipulate whether the child would be freed from the case or brought to judgment system.

Based on the explanation above, The law Number 11 Year of 2012 on the Criminal Justice System for Children was established with the aim of embodying judicial system which completely warrants the interest of the child in the conflict of law. The fundamental substance of the law is an imposing regulation on restorative justice and diversion in order to avoid or to keep children at the distance of the judicial process. It is also meant to avert stigmatization against children with the conflict of law and an expectation that the child would return to his/her social environment in a normal way.

Protection for the child with law conflict should be viewed in broadening meaning which encompasses protection for fundamental right and freedom of children and various interests concerned with child welfare (BardaNawawiArief, 1998: 153).

This statement pursuant to the content of Law Number 23 Year of 2002 Jo Law Number 35 Year of 2014 on Children Protection which asserts that children protection is every activity conducted to ensure and protect children with their rights to live, grow and develop and participate optimally in accordance with human dignity and also protection from violence and discrimination. The conclusion derived from the explanation are (1) protection of freedom of children, (2) protection of human rights of the children, (3) legal protection for all of the children interests regarding welfare (Joni, 1999: 35). Legal protection for children with law conflict drew international attention and they published various instruments of international laws such as the declaration of human rights, declaration of child rights, international standard on child justice system, etc.

The law Number 11 Year of 2012 stated that every child has the following rights: (a) to be treated in a manner by taking account his/ her interests of age. (b) to be kept separately from adults. (c) to acquire legal assistance and other kinds of assistances effectively (d) to perform recreational activities. (e) free from torture, condemnation, or any other cruel treatment, inhuman, and degrading their dignity, (f) there will be no death nor lifetime sentences for the verdict $(\mathrm{g})$ There will be no arrested, detained, or jailed except as a measure of last resort for shortest appropriate period of time, (h) to acquire justice before the child court which is objective, impartial, and close for the public ( $j$ ) there will be no disclosure of his/her identity.

A conviction for the defendant, adults or children,would not bring an immediate justice for the child victims, considering there are other problems arise even though the defendant has been convicted. Legal protection for child victims according to restorative justice implemented as follow:

(1) Making assessment program to determine the extent of the level suffering of the child victims and to submit a suggestion of relevant care and treatment in immediate time. (2) Individual intervention program aims to alleviate pain and misery and to make them return to their normal condition in immediate time. Recovery would be the final attempt of all the process of intervention through clinical method. (3) Social advocacy program in two operational locations which are the advocacy of a case and system advocacy. The advocacy of a case put the child victims to receive services needed. Advocacy system existed to represent and defend the victims in general as a class to enhance awareness and to ensure that child victims would get access to services they need, as well as to propose new policies / laws relevant and important to them. (4) Program of submitting public policy which accommodates the rights of the child victims. It can be done by synchronizing the legislations, empowering all aspects of the law, and modifying all the law and regulations that are not in accordance with the development and needs of the community and which provide less legal protection for children, especially child victims of crimes (Ali Makki, 2015: 238-239).

Crucial point in the recovery of child victims of crime is psychological side which has mentioned earlier and such procedures should be the responsibility of the state as a consequence of the implementation of the state Constitution which obliges the state to welfare all of its people, while material compensation or restitution remains a responsibility of the perpetrator as criminal prosecution.

Legal protection for child victims of crime, which discoursed recently, tends to be disadvantageous and cause additional suffering for child victims due to complicated procedures and the absence of a clear mechanism of how to claim for indemnification, restitution, and compensation that should be received by the child victim of crime. The easiest and fastest way to resolve such problems is for the court to implement a new breakthrough in both the procedural law or prosecution which later would amend various legislations oriented to the interests of the 
child in a whole.

The necessity for the fast procedure occurred when we view the article 1 item 2 jo article 4 of Law Number. 23 The year of 2002 on Child Protection which stated that child protection encompasses all activities to ensure and protect children and their rights in order to live, grow and develop and participate optimally in accordance with human dignity and protection from violence and discrimination.

The article 17 section (2) of this law also stated that any child who becomes a victim or a perpetrator of sexual abuse or conflict with the law are entitled to be kept secret, subsequently article 18 affirms that every child victim or the offender is entitled to have legal assistance and other assistance. While the special treatment for the victims can be seen in Article 59 which stated the government and other governmental institutions are obliged and responsible for providing special protection to the child victims of violence both physical and / or mental.

Implementation of article 59 is clearly explained in article 64 paragraph (3) which stated that special protection for children who become victims of crime referred to paragraph 1 is implemented through: (1) rehabilitation efforts, both within and the outside of the institution (2) Protecting attempts of exposing the identity through mass media and to avoid labeling (3) provision of safety guarantees for witnesses and expert witnesses, whether physical, mental, and social and (4) provision of accessibility to acquire information about the development of the case.

The policy of penalty inclusion in the criminal provisions of the Law Number 23 Year of 2002 on the Children Protection is extremely harmful for children only receive compensation amounting to 72 million rupiah which if it is allocated to the various programs of rehabi of child victims would certainly not be sufficient, with exception that the implementation of the program and its rules do not involve families of the child victims but merely because of the sole obligation of the state. The material compensation received (money) counts as a fund of compassion (charity) for the victims.

\section{Conclusions}

The child victims of crime should be the focus of attention in the case of law.
Discussion of children in conflict with law and children victims of crime should be the center of attention without disaggregated and divided in priorities because "children" whether as the perpetrator and victim of crime remains a state asset. Re-orientation and re-evaluation of the regulations concerning children should be integrated with social development programs for children. Law Criminal Justice System for Child, Law on Children Protection, the Child Welfare Law and Criminal Code and Criminal Law Procedure Code should be in line hand in hand in order to protect the interests of all elements encompasses the perpetrator, the victim, the community, and the state.

\section{References}

Arief, B. N. (1998). Beberapa Aspek Kebijakan dan Pengembangan Hukum Pidana. Bandung: Citra Aditya Bakti.

Arief, B. N. (1998). Beberapa Aspek Kebijaksanaan Penegakan dan Pengembangan Hukum Pidana. Bandung: Citra Aditya Bakti.

Austern, D. (1987). The Crime Victim. Victoria: Penguin Book.Forum Keadilan. (2013).

Harahap, M. Y. (2005). Pembahasan Permasalahan dan Penerapan KUHAP Pemeriksaan Sidang Pengadilan, Banding, Kasasi, dan Peninjauan Kembali. Jakarta: Sinar Grafika.

Henkes, B. (2000). The Role of Education in Juvenile Justice in Eastern Europe and The Former Soviet Union. Hungary: Constitutional and Legal Policy Institute.

Joni, M., , Z., \& Tanamas. (1999). Aspek Hukum Perlindungan Anak dalam Presfektif Konvensi Anak. Bandung: Citra Aditya Bhakti.

Joutsen, M. (1987). The Role of The Victim in Crime in European Criminal Justice System. Helsinki: Heuni.

Makki, A. (2015). Implikasi Penerapan DiversiTerhadap Tindak Pidana Anak Melalui Pendekatan Keadilan Restoratif Dalam Sistem Peradilan Pidana Anak. Jakarta: Disertasi Program Doktor IImu Hukum Pascasarjana Universitas Jayabaya.

Mudzakir. (2001). Posisi Korban Kejahatan Dalam Sistem Peradilan Pidana. Jakarta: Disertasi Doktor Universitas Indonesia.

Muladi. (1996). Kapita Selekta Sistem Peradila Pidana. Semarang: Undip.

Muladi. (2002). Hak Asasi Manusia, Politik dan Sistem Peradilan Pidana. Semarang: Badan Penerbit Undip. 
Mulyadi, L. (2007). Kapita Selekta Hukum Pidana, Kriminologi dan Viktimologi. Jakarta: Jambatan.

Mulyadi, L. (2012). Bunga Rampai Hukum Pidana Umum dan Khusus. Bandung: Alumni.

Reksodipuro, M. (1994). Hak Asasi Manusia dalam Sistem Peradilan Pidana. Jakarta:
Pusat Pelayanan Keadilan dan Pengabdian Hukum Lembaga Kriminologi UI.

Sahetapy, J. (1987). Victimologi Sebuah Bunga Rampai. Jakarta: Pustaka Sinar Harapan.

Schafer, S. (1968). The Victims and His Criminal. NY: Random House. 